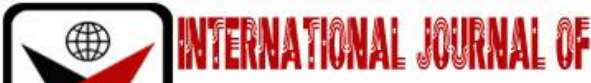

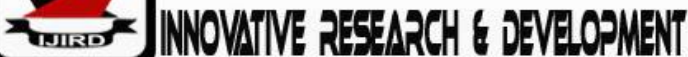

ISSN 2278 - 0211 (Online)

\section{Effect of TMT on Corporate Governance and Companies \\ Performance: Evidence from Entities Listed at the Nairobi Securities Exchange, Kenya}

Samwel Omwenga Makini
Ph.D. Student, Department of Strategic Management, University of Nairobi, Kenya
Zachary B. Awino
Professor, Department of Strategic Management, University of Nairobi, Kenya
Dr. Kennedy Ogollah
Senior Lecturer, Department of Strategic Management, University of Nairobi, Kenya
Dr. Peterson O. Magutu
Senior Lecturer, Department of Management Science, University of Nairobi, Kenya

\begin{abstract}
:
The members of top management across or rather among organizations enlist titles like chief executive officers, directors either executive or managing, presidents, assistant or vice presidents and or chairperson/chairman etcetera. The characteristics involving the teams in top management are understood as traits that are personally unique either acquired innately or the process of learning and to some extent cognitively or observations. Such traits contribute immensely to decisions which results or leads to positive impact on organizations success through quality decisions. The argument revolves around expertise that management cadres bring on a discussion table to boost the level of strategies formulation for the betterment of areas of importance to organizations thus improving growth and performance. The frauds accountability in all concerned organizations are curtailed by the practices deemed necessary in corporate governance considerations with argument revolving around weak and strong corporate governance adoption in organizations determining enhanced or reduced frauds concerning accounting functions. The concerned stakeholders like government, public, shareholders and more so investors determines the complexity and the multi-dimensional nature of firms quoted and adhering to corporate governance fundamental rules. The study was guided the upper echelons theory. A survey which is cross sectional and descriptive in nature was considered. Structured questionnaires containing closed and open questions were applied to get primary data from 66 firms listed at the NSE. The rate of return was at 75.76 percent and Hierarchical analysis in a regression model tested the hypothesis. The study found out that education, functional background and work experience, contributes highly to TMTs and firm performance linkage. These qualities should be considered key elements by policies makers when developing policies to be used when recruiting TMT. Characteristics at the top management thus moderate governance at corporate level and NSE listed firms in Kenyan context.
\end{abstract}

Keywords: Top management team, corporate governance, firm performance, Nairobi securities exchange

\section{Introduction}

The reflections surrounding teams in top management revolves around their knowledge on key aspects required to choose strategies in their key areas of functions, their values and cognitive orientations (Hambrick and Mason, 1984). The key assumption of the Upper Echelon theory (UET) is the argument that top management team characteristics are closely related to the cognitive and psychological elements of the executives' (Cannella, Park \& Lee, 2008). This gives an organization an upper hand in developing, adapting and execution those strategies that maximize the organizational power over other competing firms.The theoretical assumptions of upper echelon have resulted to enormous research materials supporting the key tenets of teams in top management and their role on performance of existing and developing firms (Kinuu, Murgor, Ongeti, Letting and Aosa, 2012). This is in line with the perception that key information generators in any organization are the decision makers who are members of the top management (Certo et al., 2006).

Drawing on the demography of the executives and the upper echelon points of view, Herrmann and Datta, (2005) studiedhowthe teams in the top management category attributes (tenure, educational level, age, functional background and international experience) and firm worldwide broadening for differentiated US-based firms in the manufacturing area. It is demonstrated that organizations with more elevated levels of universal diversification are probably going to have TMTs described by higher level of education, shorter tenures, more youthful executives and more noteworthy worldwide 
experience. The non-executive directors at a higher percentage on the board affect performance in a positive magnitude depending on the estimated coefficients at scholarly levels (Zainal Abidin et al., 2009).

Akpan and Amran (2014) on perspectives defining characteristics of the board and performance in terms of turnover in Nigeria indicated that education and also size in relation to board are key to company performance as compared to equity, independence and age relating to board which was exhibited no relationship at all. The moderating variable top management team characteristic in this study is anchored on the upper echelon theory focusing on the relationship between demographic characteristics. The theory enables the study understands the role of top management team characteristics and how their potential can be harnessed to improve organizational performance.

The complexity organizations take in to account more so in management as opposed to creating synergies surround strategies formulation or even implementation (Hambrick \& Mason, 1984).The role surrounding teams in the top management are key with the ability to form and management organizations key functional areas identified in academics and practice (Hambrick \& Mason, 1984).

It is also confirmed by studies especially in management that teams in top management creates a good working efforts that leads to improved performance. Hambrick and Mason (1984) the strategies surrounding the performance of any firm is a reciprocate of how management at the top coordinate and implement in the best way possible which are assumed to reflect values, expertise and experience which adds value to decisions made concerning the functioning of the firm (Finkelstein \& Hambrick, 1997).

The documented studies touching on corporate governance and how teams at the top management can result to performance enhancement (Praptiningsih, 2009; Guo \& Kumara, 2012; Lishenga; 2012; Machuki \& Aosa, 2011) have resulted to inconsistencies therefore challenging the role upon which researchers in management have placed on team management teams thus remaining unanswered prompting further research on the subject. The study therefore sought to determine the role top management team characteristics play in influencing performance hence the question of whether the management in terms of their key characteristics is advantageous especially in influencing governance at the corporate level and performance still remains unanswered and open for further discussion.

\section{Materials}

Empirical research has discovered that the level of experience in terms of functional areas of TMTs is decidedly connected with growth in terms of sales (Norburn and Birley 1988). Hambrick and Mason (1984) proposed connections between experience and performance in terms of finance. The subject of connections between useful experience and social worth creation, in any case, stays unexplored in the theory of upper echelon. Mauwa, (2017) considered determinants of performance of firms in the aspects of finance recorded on the Rwanda Stock Exchange utilizing secondary information and census with findings that governance related to corporate impacts performance significantly.

Mkalama (2015) on the characteristics exhibited by management team at the top and how they link to performance of corporations of the state applying descriptive survey cross sectional revealed performance as a dependent of characteristics at the top level managers. Carpenter and Fredrickson, (2001) conducted a study on top management teams, global strategic posture, and the moderating role of environment uncertainty. They showed that vulnerability is an outcome of ecological variables that by and large outcome in an absence of the data expected to evaluate implies cuts off associations, decide, and unhesitatingly allocate probabilities to their results.

Irungu (2007) studying teams at the top management and their influence especially in companies that are quoted publicly applying 29 banks data which stands at 72.5\% rate of response established a relationship which is positive between characteristics at TMTs and indicators of performance especially non-financial. Saleh et al. (2005) found that a higher level of non-executives has made frameworks of auditing which are better and improved budgetary timelines of reporting. Mutuku (2012) built up that the nature of choices in terms of quality which are made by Top managers have critical impact on the management angles identifying with inward business procedures and learning and development. Teece (1980) contends that to have the option to perceive the accessible opportunities relies upon person's capacity, ability and the aptitudes and information especially in creating informed business decisions.

Marn and Romuald (2012) in checking the effect accrued by mechanisms of governance at corporate level taking in to considerations Malaysia with its companies that are listed and census survey with data that is quantitative revealed significance between performance as influenced by size of the board and duality in terms of CEOs and also insignificance in terms of audit committees and further directorship in multiple arrangements to performance levels. Haniffa and Hudaib (2006) found that non-official executives had no impact on firm execution. This could be because of the way that in many nations that are developing including Malaysia the determination of the autonomous executives did not depend on their ability and experience however more for political motivations to authentic business exercises and agreements. The inconclusive results from various studies validate the need for this current study.

\section{Methods}

The study was based on a positivist philosophy approach. The main reason for the study adopting the positivist philosophy was based on the argument that the study set to empirically and objectively analyze the relationships existing among the variables and the hypothesis were drawn from the theories. A cross-sectional survey design which is descriptive by nature was adopted with 66 NSE firms considered. Primary and secondary data were used which were collected using questionnaires and review from firms records. The study used primary data collected using questionnaires. A close-ended questionnaire was used to collect primary data relating to the all variables. The questionnaire enabled the researcher to collect views of respondents on the manifestations of the variables of the study. The questionnaire adopted a 5-likert scale. Before administering the data collection instrument, respondents were assured of complete confidentiality 
and anonymity regarding their responses. The questionnaire was administered using the 'drop and pick up later' method so as to allow the respondents ample time to respond to the questions, thereby enhancing accuracy in responses and improve response rate. For this study, both descriptive and inferential statistic (mean scores, standard deviations, percentages and frequency distribution) were used including the regression model at a 95 percent confidence level.

\section{Results}

The study focused specifically on governance at corporate level and NSE firm's performance and also check statistically if teams at management level have any effect as moderator on the specified relationship. The results are shown in Table 1 below.

\begin{tabular}{|c|c|c|c|c|c|c|}
\hline \multicolumn{7}{|c|}{ Model Summary } \\
\hline \multirow[t]{2}{*}{ Model } & \multirow[t]{2}{*}{$\mathrm{R}$} & \multirow[t]{2}{*}{ R Square } & \multirow{2}{*}{$\begin{array}{l}\text { Adjusted R } \\
\text { Square }\end{array}$} & \multirow{2}{*}{$\begin{array}{l}\text { Std. Error of the } \\
\text { Estimate }\end{array}$} & \multicolumn{2}{|c|}{ Change Statistics } \\
\hline & & & & & $\begin{array}{c}\text { R } \\
\text { Square } \\
\text { Change }\end{array}$ & $\begin{array}{c}\mathrm{F} \\
\text { Change }\end{array}$ \\
\hline 1 & $.652^{\mathrm{a}}$ & .426 & .414 & .551 & .426 & 35.574 \\
\hline 2 & $.703^{b}$ & .495 & .473 & .523 & .069 & 6.403 \\
\hline 3 & $.721^{\mathrm{c}}$ & .520 & .510 & .525 & .037 & .641 \\
\hline \multicolumn{7}{|c|}{ ANOVA $^{a}$} \\
\hline & Model & Sum of Squares & $\mathrm{df}$ & Mean Square & $\mathrm{F}$ & Sig. \\
\hline \multirow[t]{3}{*}{1} & Regression & 10.810 & 1 & 10.810 & 35.574 & $.000^{\mathrm{b}}$ \\
\hline & Residual & 14.586 & 48 & .304 & & \\
\hline & Total & 25.396 & 49 & & & \\
\hline \multirow[t]{3}{*}{2} & Regression & 12.559 & 2 & 6.279 & 22.990 & $.000^{\mathrm{c}}$ \\
\hline & Residual & 12.837 & 47 & .273 & & \\
\hline & Total & 25.396 & 49 & & & \\
\hline \multirow[t]{3}{*}{3} & Regression & 13.735 & 3 & 4.578 & 16.648 & $.000^{\mathrm{d}}$ \\
\hline & Residual & 12.661 & 46 & .275 & & \\
\hline & Total & 26.396 & 49 & & & \\
\hline \multicolumn{7}{|c|}{ Coefficients $^{\mathbf{a}}$} \\
\hline \multirow{2}{*}{\multicolumn{2}{|c|}{ Model }} & \multicolumn{2}{|c|}{ Unstandardized Coefficients } & $\begin{array}{l}\text { Standardized } \\
\text { Coefficients }\end{array}$ & $\mathrm{t}$ & Sig. \\
\hline & & $\mathrm{B}$ & Std. Error & Beta & & \\
\hline \multirow[t]{2}{*}{1} & (Constant) & .983 & .356 & & 2.761 & .008 \\
\hline & Corporate Governance & .663 & .111 & .652 & 5.964 & .000 \\
\hline \multirow[t]{3}{*}{2} & (Constant) & .402 & .408 & & .984 & .330 \\
\hline & Corporate Governance & .569 & .112 & .560 & 5.089 & .000 \\
\hline & $\begin{array}{l}\text { Top Management } \\
\text { Characteristics }\end{array}$ & .244 & .096 & .278 & 2.530 & .015 \\
\hline \multirow[t]{4}{*}{3} & (Constant) & 1.552 & 1.494 & & 1.039 & .304 \\
\hline & Corporate Governance & .286 & .110 & .183 & 2.592 & .006 \\
\hline & $\begin{array}{l}\text { Top Management } \\
\text { Characteristics }\end{array}$ & -.265 & .104 & -.274 & -2.549 & .001 \\
\hline & interaction term & .352 & .113 & .601 & 3.130 & .007 \\
\hline
\end{tabular}

Table 1: Moderating Effect of Top Management Team Characteristics on the Relationship between Corporate Governance and Financial Performance

a. Dependent Variable: Financial Performance

b. Predictors: (Constant), Corporate Governance, Top Management Characteristics

c. Predictors: (Constant), Corporate Governance, Top Management Characteristics, interaction term

The study registered a positive and also significant coefficient of correlation $(\mathrm{R}=0.721)$ when an interaction was considered between governance at the corporate level and teams at the management level. This was also shown in the manifestation of coefficient of determination change $\left(\mathrm{R}^{2}=.520\right)$ when an interaction term has been subjected to the model. It was also reported at the overall model the significant effect $(F=16.648, P$-value $=0.000<.05)$. The beta coefficient $(\beta=$ $0.352, \mathrm{t}=3.130$, $\mathrm{P}$-value $=0.007<.05)$ was significant for interaction.

The studies of Irungu (2007) and also Mkalama (2015) suggests parameters of TMT characteristics to having influencing performance positively and significantly especially the financial indicators. It is further argued that size of the board coupled with education related to the board members positively relates to performance but equity in terms of the board, independence and age of the board does not influence performance significantly (Akpan and Amran, 2014) 


\section{Conclusion}

The study makes several conclusions and further gives an insight of the study is implicated to various managerial categories. First it is prudent to note that performance especially in firms under NSE is depend on governance at corporate level with further evidence enough to suggest teams at management level playing a significant and also strong role in this relationship as a moderator. Characteristics like work experience coupled with education and also background in terms of functional levels contributes majorly to performance with an argument that leadership at managerial level must possess them for governance at the corporate level to be effective.

\section{Implications of the Study}

At policy levels such characteristics must and ought to be taken into considerations especially when TMTs are recruited since they have clearly shown that they play a significant role in adding value to governance at corporate level thus influencing the performance aspects. Theories underpinning the study like agency theory are enriched in their prepositions along the arguments supporting TMTs, corporate governance and more so the intertwined nature of such variables in influencing firm performance.

\section{Acknowledgment}

I thank God for enabling me reach this far. The completion of this research was as a result of immense support and encouragement from many people. I would like to express my heartfelt gratitude and appreciation to my supervisors: Professor Zackary B. Awino, Doctor Kennedy Ogollah and Doctor Peterson O. Magutu who conscientiously and patiently guided and encouraged me throughout this journey. Their invaluable advice, support, constructive critique, rigorous contributions, and personal commitment went beyond the call of duty.

\section{References}

i. Akpan, E. O., \& Amran, N. A. (2014). Board characteristics and company performance: Evidence from Nigeria. Journal of Finance and Accounting, 2(3), 81-89

ii. Awino, Z.B. (2013). An empirical study of top management team diversity and performance in the service industry. Research Journal in Organizational Psychology \& Studies, 2(1): 25-31.

iii. Cannella, A. A., Park, J. \& Lee, H. (2008). Top management team functional background diversity and firm performance: examining the roles of team member co-location and environmental uncertainty. Academy of Management Journal, 51(4), 197-237

iv. Carpenter, M. A., \& Fredrickson, J. W. (2001). Top management teams, global strategic posture, and the moderating role of uncertainty. Academy of Management Journal, 44(3), 533-545.

v. Certo, S. T., Lester, R. H., Dalton, C. M., \& Dalton, D. R. (2006). Top management teams, strategy and financial performance: A meta-analytic examination. Journal of Management Studies, 43(4), 813-839. https:// doi.org/10.1111/j.1467-6486.2006.00612

vi. Finkelstein, S. \& Hambrick, D.C. (1997). Review: strategic leadership: Top executives and their effects on organizations. Australian Journal of Management, 22(2), 221-224.

vii. Guo, Z. \& Kumara, U. (2012). Corporate governance and firm performance of listed in Srilanka. Social and Behavioural Sciences, 40, 664-667.

viii. Haniffa, R., \& Hudaib, M. (2006). Corporate governance structure and performance of Malaysian listed companies. Journal of Business Finance \& Accounting, 33(7-8), 1034-1062.

ix. Hambrick, D.C. \& Mason, P.A. (1984). 'Upper Echelons': The organization as a reflection of its top managers'. Academy of Management Review, 9: 195-206.

x. Herrmann, P., \& Datta, D. K. (2005). Relationships between top management team characteristics and international diversification: An empirical investigation. British Journal of Management, 16(1), 69-78.

xi. Irungu, S.M. (2007). The effect of top management teams on the performance of publicly quoted companies. Unpublished Ph.D. Thesis. University of Nairobi, Nairobi

xii. Katz, R. (1982). The effects of group longevity on project communication and performance. Administrative Science Quarterly, 27:81-104.

xiii. Kinuu, D., Murgor, P., Ongeti, W., Nicholas, L., \& Evans, A. (2012). Upper Echelons Theory and Research: A review of theory and empirical literature 28 years later. Prime Journal of Business Administration and Management (BAM), 2(10), 697-702

xiv. Lishenga, J. (2012). Corporate governance reaction to declining firm performance: Evidence from NSE. African Journal of Business Management, 1.

xv. Machuki, V. N. \& Aosa, E. (2011). The Influence of external environment on the performance of publicly quoted companies in Kenya. Business Administration and Management Journal, 1(7), 205-2018.

xvi. Marn, J. T. K., \& Romuald, D.F. (2012). The Impact of Corporate Governance Mechanism and Corporate performance: A study of Listed Companies in Malaysia. Journal for the Advancement of Science \& Arts, 3(1), 31-45.

xvii. Mauwa, J. (2017). Determinants of Financial Performance of Firms Listed on The Rwanda Stock Exchange. Doctoral dissertation, COHRED, JKUAT.

xviii. Mkalama, R. N. (2014). Top management demographics, strategic decision making, Macro-Environment and Performance of Kenyan State Corporations. Unpublished PhD. Thesis, University of Nairobi.

xix. Mutuku, C. (2012). Factors influencing relationship between top management team diversity and performance of commercial banks in Kenya. (Unpublished doctoral dissertation), University of Nairobi 
xx. Norburn, D., \& S. Birley. (1988). The Top Management Team and Corporate Performance. Strategic Management Journal, 9 (3), 225-237.

xxi. Praptiningsih, M. (2009). Corporate governance and performance of banking firms: evidence from Indonesia, Thailand, Philippines, and Malaysia. Jurnal Manajemen dan Kewirausahaan, 11(1), 94-108.

xxii. Saleh, N. M., Iskandar, T. M., \& Rahmat, M. M. (2005). Earnings management and board characteristics: Evidence from Malaysia. Jurnal Pengurusan, 24, 77-103

xxiii. Sekaran, U. \& Bougie, R. (2009). Research method for business: a skill building approach. London: A John Wiley and Sons Ltd United Kingdom.

xxiv. Teece, D. J. 1980. Economies of scope and the scope of the enterprise. Journal of Economic Behavior and Organization, 1 (3): 223-247.

xxv. Zabri, S. M., Ahmad, K., \& Wah, K. K. (2016). Corporate governance practices and firm performance: Evidence from top 100 public listed companies in Malaysia. Procedia Economics and Finance, 35, 287-296. 